\title{
Abnormal Transmethylation/transsulfuration Metabolism and DNA Hypomethylation Among Parents of Children with Autism
}

\author{
S. Jill James · Stepan Melnyk · Stefanie Jernigan · Amanda Hubanks • \\ Shannon Rose · David W. Gaylor
}

Published online: 11 July 2008

(C) Springer Science+Business Media, LLC 2008

\section{Erratum to: J Autism Dev Disord} DOI 10.1007/s10803-008-0591-5

Please note that the first author's last name is "James", not "Jill James".
The publisher regrets the error that was made in the production of the article of rendering this coauthor's last name as "Jill James", making the article unretrievable by those searching for it using the correct last name "James".

The online version of the original article can be found under doi:10.1007/s10803-008-0591-5.

S. J. James · S. Melnyk · S. Jernigan · A. Hubanks - S. Rose Department of Pediatrics, University of Arkansas for Medical Sciences, Little Rock, AR 72202, USA

S. J. James $(\bowtie)$

Arkansas Children's Hospital Research Institute, 1120 Marshall

St. Slot 512-40B, Little Rock, AR 72202, USA

e-mail: jamesjill@uams.edu

D. W. Gaylor

Department of Biostatistics, University of Arkansas for Medical

Sciences, Little Rock, AR 72202, USA 